(iD https:/ orcid.org/0000-0002-1260-5774

\title{
Stosowanie tymczasowego aresztowania względem członka zorganizowanej grupy przestępczej w kontekście prawa jednostki do wolności
}

\begin{abstract}
The article analyses grounds for application of pretrial detention in respect of individuals who have been charged with the criminal offence of participation in an organised criminal group or with participation in an organised criminal association aiming at committing a criminal offence. The paper addresses two presumptions: 1) the presumption of fear that a suspect or the accused shall obstruct criminal proceedings because of their participation in an organised criminal group; 2 ) the presumption that the suspect or accused shall attempt to obstruct the proper conduct of the proceedings because of the threat that they will be severely punished. The author tries to answer the question whether the presumptions underlying application of pretrial detention at the early stages of criminal proceedings are sufficient for extension of pretrial detention. This is particularly important given the fact that these presumptions operate in schemes which might raise fears that orders of pretrial detention are used as an element of criminal policy against criminal groups. It must be noted that application of pretrial detention enters the sensitive realm of human rights and civil liberties. On the other hand, a failure to apply pretrial detention makes it difficult or even impossible for law enforcement authorities to effectively break up criminal networks and prevent them resurfacing. The fight of law enforcement authorities against organised crime requires application of adequate custodial and non-custodial measures by criminal justice system but is connected with a need to respect personal freedom guaranteed by the Polish Constitution and international treaties.
\end{abstract}

Keywords: criminal process, organised criminal group, pretrial detention, presumption of obstructing criminal justice, threat of severe punishment, right to freedom

Rozważania rozpocząć wypada od wskazania, iż środki zapobiegawcze, $\mathrm{w}$ tym tymczasowe aresztowanie, zostały uregulowane przez ustawodaw- 
cę w Dziale VI, Rozdziale 28 Ustawy z dnia 6 czerwca 1997 r. - Kodeks postępowania karnego ${ }^{1}$. Zasadniczym celem omawianych środków przymusu jest zabezpieczenie prawidłowego toku postępowania karnego przez zapewnienie obecności oskarżonego (podejrzanego) na wszystkich etapach procesu, jak również zabezpieczenie postępowania przed matactwem z jego strony, tak aby proces karny mógł przebiec bez przeszkód. Ustawodawca przewiduje również możliwość zastosowania środka zapobiegawczego w celu zapobieżenia nowego, ciężkiego przestępstwa².

Dopuszczalność stosowania tymczasowego aresztowania jest uzależniona od spełnienia warunków materialnych określonych w art. 249 $\S 1$ k.p.k., do których zalicza się istnienie odpowiedniej podstawy dowodowej oraz istnienie podstawy tymczasowego aresztowania. Pierwszy z warunków zakłada, że tymczasowe aresztowanie można stosować tylko wtedy, gdy zebrany materiał dowodowy wskazuje na duże prawdopodobieństwo, że oskarżony (podejrzany) popełnił przestępstwo. Drugi warunek powiązany jest z celem stosowania tymczasowego aresztowania, jakim jest zabezpieczenie prawidłowego toku procesu, a wyjątkowo zapobiegnięcie popełnieniu przez oskarżonego (podejrzanego) nowego, ciężkiego przestępstwa ${ }^{3}$. Podstawy tymczasowego aresztowania (przesłanki szczególne) zostały sprecyzowane w art. 258 \$1-3 k.p.k., są nimi:

- uzasadniona obawa ucieczki bądź ukrycia się oskarżonego (podejrzanego) (art. 258 § 1 pkt 1 k.p.k.),

- uzasadniona obawa matactwa lub innego bezprawnego utrudniania postępowania (art. $258 \S 1$ pkt 2 k.p.k.),

- grożąca oskarżonemu surowa kara (art. 258 § 2 k.p.k.),

- uzasadniona obawa popełnienia przestępstwa przeciwko życiu, zdrowiu lub bezpieczeństwu (art. 258 § 3 k.p.k.).

Tymczasowe aresztowanie stanowi ograniczenie w korzystaniu z wolności osobistej, gwarantowanej przez Konstytucję Rzeczypospolitej Polskiej oraz Konwencję o Ochronie Praw Człowieka i Podstawowych Wolności. Na gruncie stosowania tymczasowego aresztowania ma miejsce stała kolizja pomiędzy interesem podejrzanego, determinowanym chęcią pozostawania przez niego na wolności, a interesem wymiaru sprawiedliwości, jakim jest zabezpieczenie prawidłowego toku postępowania karnego. Przyznanie prymatu pierwszeństwa jednej z tych wartości zależy od danego układu okoliczności faktycznych. Wobec tego, iż prawo do wolności stanowi fundament demokratycznego państwa prawa, tymcza-

${ }^{1}$ Ustawa z dnia 6 czerwca 1997 r. - Kodeks postępowania karnego, Dz.U. 1997, nr 89, poz. 555 ze zm.

2 T. GrzegorczyK: Kodeks postępowania karnego. Komentarz. Warszawa 2014, s. 890891.

3 R. Koper et al.: Proces Karny. Warszawa 2017, s. 421 i nast. 
sowe aresztowanie winno odpowiadać założonemu celowi, przy uwzględnieniu zasady proporcjonalności oraz dyrektywy minimalizacji skutków środków zapobiegawczych określonej w art. 257 k.p.k. ${ }^{4}$, bacząc, aby nie przybrało ono formy antycypacji kary ${ }^{5}$

Rozważania dotyczące praktyki stosowania tymczasowego aresztowania wobec podejrzanych o udział w zorganizowanej grupie przestępczej lub związku mającym na celu popełnienie przestępstwa, tj. o przestępstwo stypizowane w art. 258 Kodeksu karnego ${ }^{6}$, należy rozpocząć od nakreślenia specyfiki tego rodzaju przestępczości.

Zorganizowana grupa przestępcza to coś znacznie więcej niż współsprawstwo czy luźna grupa osób zamierzająca popełnić przestępstwo. W pojęciu ,zorganizowana” tkwią warunki rzeczywistej struktury organizacyjnej (chociażby z niskim zorganizowaniem), trwałość, więzy organizacyjne w ramach wspólnego porozumienia, planowanie przestępstw, akceptacja celów grupy, trwałość zaspokojenia potrzeb grupy, werbowanie pomocników do popełnienia przestępstw, podział ról, skoordynowany sposób działania, jak również powiązania socjologiczno-psychologiczne między członkami ${ }^{7}$.Wymienione elementy przestępczego procederu nastręczają organom ścigania poważnych trudności w rozpracowaniu struktury takiej grupy, w tym ustaleniu relacji interpersonalnych pomiędzy współsprawcami, tak aby grupa została rozbita, a wszyscy jej członkowie postawieni w stan oskarżenia przed organami wymiaru sprawiedliwości. Komplikację ścigania tego rodzaju przestępczości wzmacnia dynamika czy, nierzadko, międzynarodowy zasięg działalności podejmowanej w ramach struktur przestępczych. Przełamanie zmowy milczenia i solidar-

${ }^{4}$ Zgodnie z treścią art. 257 § 1 Ustawy z dnia 6 czerwca 1997 r. Kodeks postępowania karnego, Dz.U. 1997, nr 89, poz. 555: „Tymczasowego aresztowania nie stosuje się, jeżeli wystarczający jest inny środek zapobiegawczy, § 2 Stosując tymczasowe aresztowanie, sąd może zastrzec, że środek ten ulegnie zmianie z chwilą złożenia, nie później niż w wyznaczonym terminie, określonego poręczenia majątkowego".

${ }^{5}$ Uchw. SN z dnia 22 stycznia 2003 r., I KZP 36/02. OSNwSK 2003, poz. 177; wyr. ETPC z dnia 25 stycznia 2005 r. w sprawie Enhorm p. Szwecji. LEX nr 145710.

${ }^{6}$ Art. 258 \$1 Ustawy z dnia 6 czerwca 1997 r. Kodeks karny, Dz.U. 1997, nr 88, poz. 553: „Kto bierze udział w zorganizowanej grupie albo związku mających na celu popełnienie przestępstwa lub przestępstwa skarbowego, podlega karze pozbawienia wolności od 3 miesięcy do lat 5 . § 2 Jeżeli grupa albo związek określone w $§ 1$ mają charakter zbrojny albo mają na celu popełnienie przestępstwa o charakterze terrorystycznym, sprawca podlega karze pozbawienia wolności od 6 miesięcy do lat 8 . 33 Kto grupę albo związek określone w $\S 1 \mathrm{w}$ tym mające charakter zbrojny zakłada lub taką grupą albo związkiem kieruje, podlega karze pozbawienia wolności od roku do lat 10 . §4 Kto grupę albo związek mające na celu popełnienie przestępstwa o charakterze terrorystycznym zakłada lub taką grupą lub związkiem kieruje, podlega karze pozbawienia wolności na czas nie krótszy od lat 3".

7 Post. SA w Krakowie z dnia 24 września 2015 r., II AKz 323/15. LEX nr 1797141. 
ności przestępczej osób współdziałających w popełnieniu przestępstwa, a w szczególności rozbicie jedności i lojalności członków zorganizowanych struktur przestępczych, pozwala ujawnić wszystkie osoby uwikłane w przestępczy proceder - począwszy od szefów grup zlecających popełnienie przestępstwa czy kierujących przestępstwem, przez pomocników, podżegaczy, aż po bezpośrednich wykonawców czynu zabronionego. Organy procesowe muszą przeprowadzić szereg czynności dowodowych w celu ustalenia składu liczebnego i osobowego grupy, siedziby, wyposażenia, zasad konspiracji, którymi kieruje się grupa, kierownictwa, założycieli, powiązań z innymi grupami, współpracowników spoza takiej organizacji. W tego typu sprawach dowody z osobowych źródeł dowodowych stanowią często jedyne źródło informacji. Dowody te bywają niezwykle podatne na zniekształcenie, a z powodu bezprawnych działań sprawców przestępstw tego rodzaju uzyskanie zeznań nierzadko okazuje się niemożliwe lub też powstają komplikacje związane z ich następczym odwołaniem lub zmianą treści ${ }^{8}$. Warunkiem niezbędnym do zastosowania tymczasowego aresztowania na gruncie art. $258 \S 1$ k.p.k. jest istnienie uzasadnionej obawy ucieczki, ukrycia się oskarżonego (podejrzanego), matactwa lub innego bezprawnego utrudniania postępowania karnego. Użyty przez ustawodawcę w przepisie 258 § 1 k.p.k przymiotnik ,uzasadniona” wskazuje na to, że muszą istnieć fakty motywujące tę obawę. Okoliczności uzasadniające tę obawę nie mogą mieć charakteru abstrakcyjnego, lecz realny. To oznacza, że w konkretnych realiach faktycznych muszą istnieć tego rodzaju okoliczności, które dają podstawę do przyjęcia, że oskarżony zamierza uciec, ukryć się albo bezprawnie utrudniać postępowanie kar$\mathrm{ne}^{9}$. Natomiast stosowanie izolacyjnego środka zapobiegawczego w stosunku do osoby, której postawiono zarzut udziału w zorganizowanej grupie przestępczej, nie wymaga istnienia udokumentowanych dowodowo okoliczności uzasadniających obawy destabilizacji toku procesu karnego. W odniesieniu do tej kategorii sprawców zagrożenie zakłócenia prawidłowego przebiegu procesu karnego wynika ze specyfiki czynu zabronionego określonego w przepisie art. 258 k.k. Zagadnienia te stanowić będą przedmiot rozważań w dalszej części artykułu.

Praktyka wskazuje, że główne przesłanki stosowania i przedłużania tymczasowego aresztowania wobec członków zorganizowanych grup przestępczych to: obawa matactwa, obawa ukrywania się i ucieczki podejrzanego oraz grożąca podejrzanemu surowa kara.

Generalnie w orzecznictwie panuje pogląd, że istnienie obawy matactwa powinno z reguły wynikać z konkretnych okoliczności faktycznych,

\footnotetext{
${ }^{8}$ Post. SA we Wrocławiu z dnia 23 maja 2007 r., II AKz 239/07. LEX nr 271951.

9 R. Koper et al.: Proces Karny..., s. 426.
} 
świadczących o możliwości oddziaływania na tok procesu karnego w sposób wskazany w art. $258 \S 1$ pkt 2 k.p.k. Jednakże w pewnych wypadkach na obawę matactwa może wskazywać sam charakter przestępstwa i okoliczności towarzyszące jego popełnieniu ${ }^{10}$.

W sprawach zorganizowanej przestępczości obawa matactwa w postaci wpływania na zeznania świadków, uzgadniania wersji zdarzeń przez współpodejrzanych czy chociażby wywierania nacisku na osoby przyznające się do winy jest wywodzona ze specyfiki czynu zabronionego stypizowanego w art. 258 k.k. Ta szczególna przesłanka stosowania środka zapobiegawczego opiera się na wykształconym przez judykaturę i praktykę rozumowaniu, iż członkostwo w grupie przestępczej rodzi wysokie prawdopodobieństwo wystąpienia po stronie ich uczestników chęci destabilizacji toku procesu karnego. Istota tego rozumowania zasadza się na braku istnienia bezpośrednich dowodów czy poszlak świadczących o możliwość podjęcia prób matactwa. Na podstawie ustalenia kwalifikacji prawnej zarzucanego podejrzanemu (oskarżonemu) czynu sąd wnioskuje o istnieniu obawy podjęcia przez niego bezprawnego utrudniania zbierania i utrwalania dowodów.

Przytoczone spostrzeżenia dają asumpt do stwierdzenia, iż rozumowanie, w obrębie którego obawa matactwa wywodzona jest wyłącznie ze specyfiki zarzuconego czynu zabronionego (udziału w zorganizowanej grupie przestępczej), stanowi coś na kształt funkcjonującego w teorii prawa domniemania. Powyższe wnioskowanie przybiera postać domniemania faktycznego, które można zdefiniować jako zdanie, w którym na podstawie jednego ustalonego faktu wyciąga się wnioski o istnieniu innego faktu, z uwagi na występowanie między tymi faktami powiązania przyczynowego, które uzasadnia wnioskowanie oparte na prawdopodobieństwie $^{11}$. I tak na podstawie ustalenia zarzutu popełnienia przestępstwa $\mathrm{z}$ art. 258 k.k. wyciąga się wnioski o istnieniu uzasadnionej obawy matactwa, z uwagi na korelację pomiędzy przynależnością do grupy przestępczej, a ściślej rzecz ujmując - respektowaniem typowych zasad tej grupy, a chęcią czy gotowością bezprawnego utrudniania postępowania karnego przez ich członków. Wniosek o istnieniu obawy matactwa jest oparty na prawdopodobieństwie, które zostało ukształtowane na bazie doświadczenia życiowego oraz wiedzy organów procesowych odnośnie wskazanych powyżej korelacji.

Przechodząc do bardziej szczegółowej analizy funkcjonowania w praktyce powyżej omówionego domniemania, wskazać należy, iż koncepcja interpretacyjna, którą można odnaleźć w niektórych orzeczeniach, za-

${ }^{10}$ Post. SA w Katowicach z dnia 6 sierpnia 2008 r., II AKp 115/08. LEX nr 465061.

11 R. Koper et al.: Proces Karny..., s. 358. 
kłada, że samo uczestnictwo w zorganizowanej grupie przestępczej jest okolicznością wystarczająco uzasadniającą obawę matactwa i stosowanie tymczasowego aresztowania. Wniosek o istnieniu uzasadnionej obawy matactwa wypływa ze specyfiki czynu zabronionego określonego w art. 258 k.k. Domniemanie istnienia ze strony członków zorganizowanej grupy przestępczej chęci bezprawnego zakłócenia toku procesu karnego oparte jest na takich faktach jak: znajomość uczestników grupy, wzajemne powiązania, istnienie dróg przepływu informacji, solidarność grupowa. Sprawcy z postawionym zarzutem z art. 258 k.k. stosują przeróżne metody wywierania wpływu na uczestników procesu, od gróźb aż po przekazywanie środków do życia rodzinom uczestników. Według reprezentantów szerokiego pojmowania domniemania obawy matactwa odnosi się ono do każdego rodzaju członka zorganizowanej grupy przestępczej, zarówno inspiratora grupy, jak również szeregowego jej uczestnika. Zatem obawa matactwa jest przyjmowana na zasadzie domniemania względem wszystkich sprawców pozostających pod zarzutem z art. 258 k.k.

W orzecznictwie spotkać można również koncepcje wprowadzające ograniczenia na płaszczyźnie materializacji domniemania obawy matactwa $\mathrm{w}$ sprawach dotyczących zorganizowanej przestępczości. W judykaturze istnieją głosy rezygnujące z przyjmowania a priori, iż udział każdego sprawcy $\mathrm{w}$ zorganizowanej grupie przestępczej rodzi obawę matactwa uzasadniającą stosowanie tymczasowego aresztowania. Podkreśla się, że obawa matactwa nabiera realnych kształtów w odniesieniu do podejrzanych o kierowanie zorganizowaną grupą przestępczą z racji podporządkowania sobie $\mathrm{w}$ ramach wewnętrznej struktury organizacyjnej grupy innych jej członków, a tym samym możliwości sterowania nimi w sposób dowolny i nieograniczony także na użytek procesu. Natomiast rola podrzędna nie predestynuje do działań mataczących ${ }^{12}$. Na tle powyższego wydaje się, że w ocenie zwolenników tego zapatrywania nie jest uprawnione posługiwanie się na gruncie art. 258 § 1 pkt 2 k.p.k. uogólnieniami, sprowadzającymi się do przypisywania każdemu podejrzanemu (oskarżonemu) o udział w grupie przestępczej chęci utrudniania prawidłowego przebiegu postępowania karnego. U źródła tego poglądu leży przekonanie, że wyłącznie kierownicza rola w przestępnym procederze stwarza presumpcję do podejmowania bezprawnego zakłócenia toku procesu karnego w drodze wpływania na zachowanie, w tym zachowanie procesowe, osób pełniących podrzędną rolę w grupie przestępczej. Wreszcie na uwa-

12 Post. SA w Katowicach z dnia 15 stycznia 2003 r., II AKz 1249/02. OSA 2003/7/74, Prok. i Pr. - wkł. 2003/10/20, KZS 2003/4/69, KZS 2003/4/79, LEX nr 80604; post. SA w Krakowie z dnia 23 czerwca 2005 r., II AKz 240/05. KZS 2005/6/45, Prok. i Pr. - wkł. 2006/2/36, LEX nr 156117; post. SA w Krakowie z dnia 15 października 2008 r., II AKz 495/00. LEX nr 559920. 
gę zasługuje teza judykatów, sprowadzająca się do stwierdzenia, że sam fakt, iż podejrzanemu postawiono zarzut udziału w zorganizowanej grupie przestępczej, nie daje możliwości do wysnucia uprawnionego wniosku, że podejrzany będzie podejmował bezprawne działania utrudniające postępowanie. Takie rozumowanie byłoby nieuprawnionym domniemaniem $^{13}$. Istota tej koncepcji zakłada, że domniemanie obawy matactwa wynikające li tylko z faktu postawienia zarzutu udziału w zorganizowanej grupie przestępczej nie może być przyjmowanie w nieskończoność. Pewne okoliczności procesowe wykluczają możliwość wysnucia uprawnionego wniosku, że podejrzany (oskarżony) będzie podejmował bezprawne działania utrudniające postępowanie. Sąd Apelacyjny w Lublinie w uzasadnieniu postanowienia z dnia 7 czerwca 2006 r. $^{14}$ wskazał na następujące okoliczności przemawiające za nieprzedłużeniem tymczasowego aresztowania względem podejrzanego o udział w grupie przestępczej: prawie roczny okres pobytu podejrzanego w areszcie śledczym, brak podjęcia przez niego w tym czasie bezprawnych czynności oraz fakt, iż przeprowadzone czynności dowodowe od pół roku nie są praktycznie związane z podejrzanym. Sąd ten wywiódł konkluzję o braku okoliczności faktycznych uzasadniających przesłankę określoną w art. $258 \S 1$ pkt 2 k.p.k.

Na aprobatę zasługuje stanowisko optujące za przyjęciem, iż uczestnictwo w zorganizowanej grupie przestępczej jest okolicznością wystarczająco uzasadniającą obawę matactwa w rozumieniu art. 258 \$1 pkt 2 k.p.k. Nie trzeba w przypadku tego rodzaju sprawców wskazywać konkretnych dowodów, które przemawiałyby za podejmowaniem przez nich działań stanowiących bezprawne utrudnianie postępowania karnego. Wszak nie nastręcza wątpliwości teza, że w sprawach o działalność grupy zorganizowanej w celu popełnienia przestępstw obawa matactwa jest wielce prawdopodobna. Argument, który potwierdza tę obawę, odwołuje się do specyfiki czynu zabronionego określonego w art. 258 k.k. Trzeba przyznać rację temu, iż uczestniczenie $\mathrm{w}$ zorganizowanych strukturach przestępczych wiąże się z sui generis postacią relacji i wzajemnych powiązań, a także zależności pomiędzy uczestnikami tego typu form działalności przestępnej. Zasadniczym celem struktur przestępczych jest to, aby pozostać nieujawionym. Ich członkowie są gotowi podjać wszelkie środki, aby nie doprowadzić do wyjawienia tożsamości uczestników grupy, metod działania czy miejsca ukrycia korzyści pochodzących z przestępstw popełnionych w ramach przynależności do grupy. Podejrzany przebywa-

${ }^{13}$ Post. SA w Lublinie z dnia 7 czerwca 2006 r., II AKp 19/06. LEX nr 192836; post. SA w Lublinie z dnia 6 maja 2009 r., II AKz 261/09. LEX nr 513116.

${ }^{14}$ Post. SA w Lublinie z dnia 7 czerwca 2006 r., II AKp 19/06. LEX nr 192836. 
jąc na wolności, miałyby nieograniczone możliwości podejmowania kontaktów z innymi osobami, w tym nakłaniania ich do składania fałszywych zeznań i wyjaśnień oraz uzgodnienia wspólnych wersji wydarzeń między współsprawcami, korzystnych zarówno dla nich, jak i dla siebie. Zatem presumpcja obawy zakłócenia toku procesu wywodzona wyłącznie z członkostwa $\mathrm{w}$ grupie przestępczej stanowi wniosek logiczny oraz empiryczny. Warto odnotować, iż powyższe zapatrywanie podziela również sam ETPC ${ }^{15}$. Błędem byłoby założenie, że obawa matactwa nabiera realnych kształtów wyłącznie co do podejrzanych o kierowanie zorganizowaną grupą przestępczą, a rola podrzędna nie implikuje działań mataczących. Jak widać, pogląd ten jest bardzo liberalny w swojej istocie, jednakże w pełni nie oddaje rzeczywistości. W przypadku każdego członka zorganizowanej grupy przestępczej, a nie wyłącznie kierownika czy pomysłodawcy, zachodzi realna obawa podjęcia przez niego działań zakłócających prawidłowy tok procesu. Osoba pełniąca funkcję kierownika czy pomysłodawcy zajmuje silną pozycję w grupie, która może zostać wykorzystana w celu wpływania m.in. na zachowania procesowe pozostałych uczestników. $Z$ tych względów zatrzymanie tego typu osób stanowi zminimalizowanie ryzyka utrudniania postępowania karnego poprzez wpływanie na zeznania świadków czy współuczestników przestępstwa. Powyższe rozważania zachowują aktualność również w odniesieniu do szeregowych członków grup przestępczych. Przeciwne stanowisko nie znajduje uzasadnienia $\mathrm{w}$ realiach polskiej przestępczości, w której bardzo często osoby zajmujące rolę podrzędną mają za zadanie „ochraniać” kierowników grup przestępczych poprzez stosowanie systemu ostrzeżeń przed organami ścigania oraz niesienia pomocy w ukryciu czy ucieczce poza granice kraju. W tym kontekście wymaga zaznaczenia, iż skuteczność prawnokarnej reakcji na przestępczość zorganizowaną $\mathrm{w}$ dużym stopniu uzależniona jest od wykrycia i zatrzymania osób, które stoją na czele zorganizowanych struktur przestępczych. Oczywiście także w stosunku do kategorii osób zajmujących rolę podrzędną zachodzi obawa wpływania na zeznania świadków czy współpodejrzanych chociażby celem umniejszenia swojej roli w przestępczym procederze. Solidarność grupowa oraz akceptacja celów grupy powodują, że w przypadku osób zajmujących podrzędną rolę w organizacji realnych kształtów nabiera występująca po ich stronie gotowość bezprawnego utrudniania postępowania karnego również w postaci zacierania śladów przestępstwa. Może się okazać, iż pozycja danego członka w przestępstwie była drugoplanowa, lecz na etapie rozpoznania sprawy odizolowanie go od społeczeństwa stanowi jedyny środek za-

15 Post. SA w Krakowie z dnia 15 października 2008 r., II AKz 495/08. LEX nr 559920; wyr. ETPC z dnia 13 września 2011 r. w sprawie Bystrowski p. Polsce (skarga nr 15476/06). LEX nr 898138. 
pewniający niezakłócony tok procesu karnego i dojście do prawdy materialnej.

Domniemanie obawy matactwa wywodzone ze specyfiki czynu zabronionego stypizowanego w art. 258 k.k. nie może być uznane za bezwzględne w tym sensie, że będzie w nieskończoność bezrefleksyjnie przyjmowane jako uzasadnienie stosowania izolacyjnego środka zapobiegawczego. Jakkolwiek w sprawach dotyczących zorganizowanej przestępczości, złożonych pod względem podmiotowym oraz przedmiotowym, cechujących się wysokim stopniem demoralizacji uczestników, usprawiedliwiony jest większy rygoryzm w zakresie stosowania tymczasowego aresztowania, niemniej kwalifikacja prawna zarzutu nie może stanowić okoliczności uzasadniającej stosowanie tymczasowego aresztowania przez długie okresy. Zgodnie z orzecznictwem ETPC oczywiste jest, iż w sprawach dotyczących zorganizowanej przestępczości ciągła kontrola i ograniczenia kontaktu oskarżonych pomiędzy sobą i z innymi osobami może mieć zasadnicze znaczenie dla uniemożliwienia im ucieczki, przeprowadzenia ingerencji w dowody oraz, co najważniejsze, wpływania na świadków, a nawet grożenia im. W związku tym dłuższe okresy stosowania tymczasowego aresztowania mogą być $\mathrm{w}$ tych sprawach bardziej uzasadnione niż $\mathrm{w}$ innych ${ }^{16}$. Trybunał stoi na stanowisku, że istnienie generalnego ryzyka wynikającego ze zorganizowanego charakteru zarzucanej działalności przestępczej może zostać uznane za podstawę aresztowania na wstępnych etapach postępowania, a w pewnych okolicznościach także dla późniejszego przedłużenia tymczasowego aresztowania ${ }^{17}$. Trwające nawet kilka lat stosowanie tymczasowego aresztowania w oparciu li tylko o domniemanie wiążące ryzyko ucieczki i utrudnianie postępowania wynikające $\mathrm{z}$ faktu postawienia zarzutu popełnienia poważnego przestępstwa, bez istnienia i dostrzeżenia innych okoliczności i faktów, które by to domniemanie wzmacniało, stanowi naruszenie gwarancji ujętej $\mathrm{w}$ treści art. 5 ust. 3 Konwencji ${ }^{18}$. Domniemanie podejmowania przez sprawcę zachowań utrudniających postępowanie nie może być przyjmowane w nieskończoność i z biegiem toczącego się postępowania podlega ono weryfikacji na rzecz konkretnych ustaleń o zaistnieniu wynikających z niego przesłanek procesowych stosowania tymczasowego aresztowania. Przedłużenie tymczasowego aresztowania mogą uzasadniać tylko bezsporne i pewne ustalenia, że żaden inny środek nie jest w stanie zagwarantować prawidłowego toku prowadzonego postępowania. Waga zarzu-

16 Wyr. ETPC z dnia 7 października 2008 r. (skarga nr 6767/03). LEX nr 456955.

17 Wyr. ETPC z dnia 10 marca 2015 r. (skarga nr 29345/09). LEX nr 1652023.

18 Post. SA w Lublinie z dnia 7 grudnia 2006 r., II AKz 333/06. LEX nr 269129; wyr. ETPC z dnia 10 marca 2015 r. (skarga nr 29345/09). LEX nr 1652023. 
canego czynu czy grożąca długoterminowa kara pozbawienia wolności nie mogą, zdaniem ETPC, stanowić samodzielnej przesłanki długotrwałego stosowania aresztu ${ }^{19}$.

W postanowieniach o zastosowaniu tymczasowego aresztowania oraz $\mathrm{w}$ postanowieniach o przedłużeniu stosowania tego środka sądy wskazywały oprócz przesłanki z art. $258 \S 1$ pkt 2 również przesłankę wymienioną w art. 258 § 2 k.p.k., dotyczącą grożącej sprawcy surowej kary. Zgodnie z treścią tego przepisu, jeżeli oskarżonemu zarzuca się popełnienie zbrodni lub występku zagrożonego karą pozbawienia wolności, której górna granica wynosi co najmniej 8 lat, albo gdy sąd pierwszej instancji skazał go na karę pozbawienia wolności nie niższą niż 3 lata, potrzeba zastosowania tymczasowego aresztowania w celu zabezpieczenia prawidłowego toku postępowania może być uzasadniona grożącą oskarżonemu surową karą. Obecne brzmienie przepisu zostało nadane $\mathrm{w}$ drodze noweli $\mathrm{z}$ kwietnia $2016 \mathrm{r}^{20} . \mathrm{Z}$ treści uzasadnienia wynika, że przesłankę z art. 258 \$ 2 k.p.k. należy traktować jako samodzielną podstawę stosowania tymczasowego aresztowania ${ }^{21}$. Wątpliwości budzi nieprecyzyjność przepisu art. 258 § 2 k.p.k., dająca sądowi dużą swobodę w zakresie podejmowania decyzji aresztowej2. W tym miejscu na uwagę zasługuje uchwała Sądu Najwyższego podjęta w składzie siedmiu sędziów z dnia 19 stycznia 2012 r., sygn. akt I KZP 18/11, w której Sąd Najwyższy stwierdził, że podstawy stosowania tymczasowego aresztowania, określone w art. 258 § 2 k.p.k., przy spełnieniu przesłanek wskazanych w art. 249 \$1 k.p.k. i art. $257 \S 1$ k.p.k. i przy braku przesłanek negatywnych określonych w art. 259 § 1 i 2 k.p.k. stanowią samodzielne przesłanki szczególne stosowania tego środka zapobiegawczego ${ }^{23}$. Przedmiotowa uchwała spotkała się w doktrynie zarówno z aprobatą ${ }^{24}$, jak również z krytyką ${ }^{25}$. Także w orzecznictwie można znaleźć stanowisko, zgodnie z którym brzmienie art. 258 $\S 2$ k.p.k. nie uprawnia do samodzielnego powoływania art. 258 § k.p.k.

19 Wyr. ETPC z dnia 23 lutego 2016 r. w sprawie Matczak p. Polsce (skarga nr 26649/12); wyr. ETPC z dnia 13 września 2011 r. (skarga nr 15476/06). LEX nr 898138.

${ }^{20}$ Ustawa z dnia 11 marca 2016 r. o zmianie ustawy - Kodeks postępowania karnego oraz niektórych innych ustaw, Dz.U. 2016, poz. 437.

${ }^{21}$ Uzasadnienie projektu ustawy o zmianie ustawy - Kodeks postępowania karnego oraz niektórych innych ustaw (Druk sejmowy nr 207,150, Sejm VIII kadencji).

${ }^{22}$ R. KOPER et al.: Proces Karny..., s. 426.

${ }^{23}$ Uchw. SN z dnia 19 stycznia 2012 r., I KZP 18/11. LEX nr 1102081.

24 D. Drajewicz: Glosa do uchwaty Sądu Najwyższego z dnia 19 stycznia 2012 r., I KZP 18/11. Prok. i Pr. 2013, nr 10.

25 J. SкоRUPKA: Glosa do uchwaty Sąu Najwyższego z dnia 19 stycznia 2012r., I KZP 18/11. OSP $2012 \mathrm{nr} 7-8$, poz. 80; M. Drewicz: Glosa do uchwaty Sądu Najwyższego z dnia 19 stycznia 2012 r., I KZP 18/11. CPKNP 2012, nr 3. 
jako podstawy stosowania bądź przedłużania tymczasowego aresztowania. W pierwszej kolejności wskazać należy, że dla możliwości zastosowania tymczasowego aresztowania w oparciu o przywołany przepis konieczne jest ustalenie, że podejrzanemu (oskarżonemu) w konkretnej sprawie grozi surowa kara. Niezbędne jest odniesienie się do kary realnie grożącej, a nie abstrakcyjnego zagrożenia ${ }^{26}$. Sąd winien wykazać z odpowiednio wysokim stopniem prawdopodobieństwa, jaka kara powinna zostać wymierzona oskarżonemu w oparciu o materiał dowodowy stanowiący podstawę decyzji o tymczasowym aresztowaniu. W judykaturze panuje pogląd, iż ustawodawca w przepisie art. 258 § 2 k.p.k. wprowadził domniemanie, iż surowość grożącej oskarżonemu kary rodzi zakłócenie toku postępowania, a to z kolei powoduje potrzebę zabezpieczenia jego prawidłowego toku poprzez stosowanie tymczasowego aresztowania ${ }^{27}$. Groźba surowej kary rodzi domniemanie, że osoby podejrzane (oskarżone) o przestępstwo mogą podejmować próby bezprawnych działań zakłócających tok postępowania. Przedmiotowe domniemanie wprowadza uproszczenie dowodowe pozwalające na przyjęcie, iż w razie wystąpienia przesłanki w postaci wysokiego realnego zagrożenia kary (podstawa domniemania) można stwierdzić potrzebę stosowania tymczasowego aresztowania (wniosek domniemania $)^{28}$. Prognozując karę, sąd jest zobowiązany uwzględnić zarówno ogólne, jak i szczególne dyrektywy sądowego wymiaru kary. W tym miejscu wymaga zaakcentowania, że postawienie przed sądem - decydującym o tymczasowym aresztowaniu - wymogu prognozowania wysokości kary stanowi naruszenie gwarancji procesowych, ponieważ prowadzi do domniemania sprawstwa czynu zabronionego oraz winy przed wydaniem wyroku, co stoi w sprzeczności z art. 42 ust. 3 Konstytucji oraz art. $5 \S 1$ k.p.k. ${ }^{29}$. Wskazana jest również teza, iż koncepcja samodzielności szczególnej przesłanki tymczasowego aresztowania określonej w art. 258 $\S 2$ k.p.k. stanowi naruszenie międzynarodowych standardów praw człowieka. ETPC wskazuje jednoznacznie, że przesłanka grożącej oskarżonemu surowej kary nie może stanowić istotnej i wystarczającej podstawy do aresztowania ${ }^{30}$. Konkludując, uznać należy, że zasadne pozostaje stwierdzenie, iż grożąca podejrzanemu (oskarżonemu) surowa kara nie powinna stanowić autonomicznej podstawy stosowania izolacyjnego środka zapo-

${ }^{26}$ D. ZAJĄC: Zagrożenie kara jako przesłanka stosowania tymczasowego aresztowania. CPKNP 2018, nr 4.

27 Post. SA w Katowicach z dnia 4 lipca 2001 r., II KK 488/01. Prok. i Pr. 2002, nr 5, poz. 33.

28 D. ZająC: Zagrożenie karq jako przesłanka...

29 M. Drewicz: Glosa do uchwały Sądu Najwyższego...

${ }^{30}$ Wyr. ETPC z dnia 23 czerwca 2005 r. w sprawie 44722/98. LEX nr 153396; wyr. ETPC z dnia 4 października 2005 r. w sprawie 9190/03. LEX nr 157757. 
biegawczego. Winna towarzyszyć obawie ucieczki, matactwa lub innemu bezprawnemu sposobowi utrudniania postępowania karnego.

Bezkrytyczne przyjmowanie domniemania podejmowania prób bezprawnego utrudniania postępowania karnego sprawia, że to na oskarżonego zostaje nałożony ciężar udowodnienia, iż po jego stronie - pomimo udziału w zorganizowanej grupie przestępczej i grożącej mu surowej kary nie zachodzi obawa matactwa, interpretowana jako wszelka działalność oskarżonego polegająca na bezprawnym utrudnianiu zbierania lub utrwalania dowodów. Bezrefleksyjne stosowanie domniemania bezprawnego zakłócania toku procesu karnego może z kolei prowadzić do naruszenia domniemania niewinności, albowiem ciężar dowodu zostaje przeniesiony z oskarżyciela na oskarżonego. Domniemania stanowią ułatwienie dowodowe dla oskarżyciela publicznego, który jest zwolniony od szczegółowego uzasadnienia podstawy dowodowej wniosku o tymczasowe aresztowanie. Ciężar obalenia faktu implikowanego przez domniemanie faktyczne, tj. prawdopodobieństwa zakłócenia prawidłowego toku postępowania karnego, spoczywa na podejrzanym (oskarżonym), który przeczy istnieniu tego faktu. W tym miejscu warto się zastanowić nad tym, czy istnieje realna szansa na wzruszenie przedmiotowych domniemań.

Dotychczasowe rozważania pozwalają stwierdzić, że na początkowym etapie postępowania przygotowawczego skuteczne wzruszenie przez członka grupy przestępczej domniemania obawy matactwa bądź domniemania ucieczki jest $\mathrm{w}$ zasadzie znacznie utrudnione. Istnienie niebezpieczeństwa matactwa wynika z samej istoty zarzutu z art. 258 k.k. Zatem trudna do przeforsowania będzie argumentacja przeciwko tymczasowemu aresztowaniu, zasadzająca się na założeniu, iż skoro w toku postępowania podejrzany nie podejmował takich działań, stawiał się na wezwania organów ścigania, to nie zachodzi przesłanka szczególna zastosowania izolacyjnego środka zapobiegawczego. Idąc o krok dalej, nasuwa się pytanie, czy domniemanie utrudniania postępowania karnego jest również aktualne wówczas, gdy podejrzany przyznaje się do zarzucanych mu czynów, składa obszerne wyjaśnienia oraz pozostaje do dyspozycji organów ścigania. Czy może te okoliczności pozwolą uwolnić się podejrzanemu (oskarżonemu) od ciążącego na nim domniemania faktycznego wynikającego z udziału w zorganizowanej grupie przestępczej? Analiza orzecznictwa prowadzi do konkluzji, że przy podejmowaniu decyzji o zastosowaniu środka zapobiegawczego sądy nie nadają powyższym okolicznościom znaczenia tego rodzaju, ażeby odstąpić od zastosowania tymczasowego aresztowania na rzecz nieizolacyjnych środków zapobiegawczych. Zgodnie $\mathrm{z}$ orzecznictwem nawet przyznanie się podejrzanego do winy nie powoduje ustania obawy matactwa, wszak każdy podejrzany może zmienić wyjaśnienia na kolejnych etapach postępowania, jak również skłonić 
do tego inne osoby celem uniknięcia odpowiedzialności karnej ${ }^{31}$. W szczególności w początkowych etapach postępowania przygotowawczego interes wymiaru sprawiedliwości jest przedkładany nad interes podejrzanego. Postawa polegająca na współpracy z organami ścigania, co prawda, zasługuje na aprobatę, lecz nie sprawia, iż przesłanka matactwa, ucieczki czy ukrywania się podejrzanego nabiera mniejszego znaczenia. Wskazuje się, że taka postawa, w przypadku pozytywnego zweryfikowania jej prawdziwości, może zostać uwzględniona na dalszym etapie postępowania, w czasie podejmowania decyzji o potrzebie i zasadności dalszego przedłużania stosowania tymczasowego aresztowania, jak również na etapie podejmowania decyzji o wymiarze kary ${ }^{32}$. Również wniosek o dobrowolne poddanie się karze nie może automatycznie przemawiać za bezcelowością dalszego stosowania tymczasowego aresztowania ${ }^{33}$.

Europejski Trybunału Praw Człowieka w Strasburgu wielokrotnie badał procedurę stosowania tymczasowego aresztowania w Polsce przez pryzmat art. 5 i 6 Europejskiej Konwencji o Ochronie Praw Człowieka i Podstawowych Wolności. Stawiane przez Trybunał zarzuty przeciwko polskiej praktyce stosowania środków zapobiegawczych oscylują wokół braku rozważenia środków alternatywnych w stosunku do tymczasowego aresztowania oraz długotrwałego stosowania omawianego izolacyjnego środka zapobiegawczego. Złoty środek pomiędzy zapewnieniem poszanowania zarówno interesu podejrzanego w kontekście nieingerowania w jego wolność, jak również interesu wymiaru sprawiedliwości leży w tym, aby w stosunku do członków zorganizowanych grup przestępczych najsurowszy środek zapobiegawczy stosować na najbardziej newralgicznych etapach procesu w momencie gromadzenia zasadniczych dowodów sprawstwa. Obawa matactwa czy ucieczki wynikająca tylko i wyłącznie z kwalifikacji prawnej czynu oraz grożącej surowej kary stanowi niewystarczającą podstawę stosowania tymczasowego aresztowania przez długie okresy. Przy podejmowaniu decyzji o przedłużeniu tymczasowego aresztowania należy mieć na względzie rolę podejrzanego w przestępczym procederze, postawę prezentowaną przez niego w toku procesu, jak również procesową funkcję tymczasowego aresztowania. Na późniejszych etapach postępowania, o ile jest to możliwe, należałoby rozważyć zastosowanie nieizolacyjnych środków zapobiegawczych. W sprawach dotyczą-

31 Post. SA w Katowicach z dnia 3 listopada 2006 r., II AKz 696/06, LEX nr 217025; post. SA w Katowicach z dnia 4 lipca 2001 r., II AKz 488/01. OSA 2002/2/15, Prok. i Pr. wkł. 2002/5/33, LEX nr 50083.

32 Post. SO w Częstochowie z dnia 29 czerwca 2017 r., VII Kz 284/17. LEX nr 2331780.

${ }_{33}$ Post. SA w Katowicach z dnia 10 października 2008 r., II AKz 677/08. LEX nr 47775. 
cych tego rodzaju przestępczości, gdzie zachodzi obawa matactwa, obawa ucieczki oraz ukrywania się sprawcy, sądy rzadko sięgają po alternatywne środki zapobiegawcze, ponieważ nie zapewniają one takiej skuteczności jak odizolowanie jednostki od społeczeństwa. Przy przedłużeniu stosowania tymczasowego aresztowania niewystarczające jest oparcie orzeczenia jedynie na stwierdzeniu zagrożenia surową karą, działania w ramach zorganizowanej grupy przestępczej i wynikającej z tego obawy matactwa czy ucieczki, szczególnie gdy ma to miejsce na etapie postępowania rozpoznawczego, kiedy oskarżony został przesłuchany, a zasadnicze dowody zostały przeprowadzone. Zgodnie z zasadą minimalizacji i proporcjonalności środków zapobiegawczych winne być one wykorzystane przez organ procesowy w sposób adekwatny do istniejącego zagrożenia dla prawidłowego toku procesu. Należy przychylić się do stanowiska ETPC, w myśl którego domniemanie podejmowania przez sprawcę zachowań utrudniających postępowanie nie może być przyjmowane w nieskończoność i z biegiem toczącego się postępowania podlega ono weryfikacji na rzecz konkretnych ustaleń o zaistnieniu wynikających z niego przesłanek procesowych stosowania tymczasowego aresztowania. Sąd, rozstrzygając o fundamentalnej wolności obywatelskiej, jest zobowiązany do szczególnej dbałości o sprawność i efektywność przedsiębranych poszczególnych czynności procesowych oraz ciągłej kontroli, czy w dalszym ciągu istnieją przesłanki uzasadniające dalsze stosowanie tymczasowego aresztowania.

\section{Bibliografia}

\section{Literatura}

Drajewicz D.: Glosa do uchwaty Sąu Najwyższego z dnia 19 stycznia 2012r., I KZP 18/11. Prok. i Pr. 2013, nr 10.

Drewicz M.: Glosa do uchwały Sqdu Najwyższego z dnia 19 stycznia 2012r., I KZP 18/11. CPKNP 2012, nr 3.

GrZegorczyK T.: Kodeks postepowania karnego. Komentarz. Warszawa 2014.

Koper R. et al.: Proces Karny. Warszawa 2017.

SKORUPKa J.: Glosa do uchwały Sadu Najwyższego z dnia 19 stycznia 2012r., I KZP 18/11. OSP 2012, nr 7-8, poz. 80.

ZAJąC D.: Zagrożenie kara jako przesłanka stosowania tymczasowego aresztowania. CPKNP 2018, nr 4.

\section{Orzecznictwo}

Uchw. SN z dnia 22 stycznia 2003 r., I KZP 36/02. OSNwSK 2003, poz. 177.

Uchw. SN z dnia 19 stycznia 2012 r., I KZP 18/11. LEX nr 1102081.

Post. SA w Katowicach z dnia 4 lipca 2001 r., II AKz 488/01. OSA 2002/2/15, Prok. i Pr. - wkł. 2002/5/33, LEX nr 50083. 
Post. SA w Katowicach z dnia 15 stycznia 2003 r., II AKz 1249/02. OSA 2003/7/74, Prok. i Pr. - wkł. 2003/10/20, KZS 2003/4/69, KZS 2003/4/79, LEX nr 80604. Post. SA w Krakowie z dnia 23 czerwca 2005 r., II AKz 240/05. KZS 2005/6/45, Prok. i Pr. - wkł. 2006/2/36, LEX nr 156117.

Post. SA w Krakowie z dnia 21 kwietnia 2006 r., II AKz 111/06. KZS 2006/4/40, LEX nr 183441.

Post. SA w Katowicach z dnia 5 maja 2006 r., II AKz 281/06. LEX nr 191733. Post. SA w Lublinie z dnia 7 czerwca 2006 r., II AKp 19/06. LEX nr 192836.

Post. SA w Katowicach z dnia 3 listopada 2006 r., II AKz 696/06. LEX nr 217025.

Post. SA w Lublinie z dnia 7 grudnia 2006 r., II AKz 333/06. LEX nr 269129.

Post. SA w Krakowie z dnia 11 stycznia 2007 r., II AKz 527/06. KZS 2007/2/37, LEX nr 268877.

Post. SA w Katowicach z dnia 17 stycznia 2007 r., II AKz 21/07. KZS 2007/5/85, LEX nr 273653.

Post. SA we Wrocławiu z dnia 23 maja 2007 r., II AKz 239/07. LEX nr 271951.

Post. SA w Krakowie z dnia 18 marca 2008 r., II AKz 128/08. KZS 2008/5/69, Prok. i Pr. - wkł. 2008/11/38, LEX nr 423393.

Post. SA w Katowicach z dnia 6 sierpnia 2008 r., II AKp 115/08. LEX nr 465061. Post. SA w Krakowie z dnia 14 sierpnia 2008 r., II AKz 424/08. KZS 2008/10/45, LEX nr 477987.

Post. SA w Katowicach z dnia 10 października 2008 r., II AKz 677/08. LEX nr 47775.

Post. SA w Krakowie z dnia 15 października 2008 r., II AKz 495/00. LEX nr 559920.

Post. SA w Lublinie z dnia 6 maja 2009 r., II AKz 261/09. LEX nr 513116.

Post. SA w Krakowie z dnia 7 września 2009 r., II AKz 118/09. KZS 2009/5/42, LEX nr 517089.

Post. SA w Katowicach z dnia 9 września 2009 r., II AKz 592/09. LEX nr 553815.

Post. SA w Krakowie z dnia 5 lutego 2014 r., II AKz 34/14. KZS 2014/2/43, LEX nr 1466273.

Post. SA w Krakowie z dnia 10 lipca 2014 r., II AKz 265/14. KSZ 2014/78/71, LEX nr 1574399.

Post. SA w Krakowie z dnia 24 września 2015 r., II AKz 323/15. LEX nr 1797141.

Post. SO w Częstochowie z dnia 29 czerwca 2017 r., VII Kz 284/17. LEX nr 2331780.

Post. SA w Krakowie z dnia 15 września 2017 r., II AKz 353/17. KZS 2017/9/60, LEX nr 2521584.

Post. SO we Wrocławiu z dnia 18 listopada 2010 r., III Kp 1161/10.

Post. SO we Wrocławiu z dnia 15 września 2011 r., III Kp 1517/11.

Post. SO we Wrocławiu z dnia 6 grudnia 2012 r., III Kp 1400/12.

Post. SO we Wrocławiu z dnia 24 stycznia 2013 r., III Kp 85/13.

Post. SO we Wrocławiu z dnia 24 stycznia 2013 r., III Kp 107/13.

Post. SO w Częstochowie z dnia 20 lutego 2014 r., VII Kz 63/14. LEX nr 1892651.

Post. SO we Wrocławiu z dnia 7 marca 2013 r., III Kp 412/13.

Post. SO we Wrocławiu z dnia 14 marca 2013 r., III Kp 419/13. 
Post. SO we Wrocławiu z dnia 14 marca 2013 r., III Kp 447/13, LEX nr 1882347.

Post. SO we Wrocławiu z dnia 14 marca 2013 r., III Kp 448/13. LEX nr 1882348. Wyr. ETPC z dnia 25 stycznia 2005 r. w sprawie Enhorm p. Szwecji. LEX nr 145710.

Wyr. ETPC z dnia 23 czerwca 2005 r. (skarga nr 44722/98). LEX nr 153396.

Wyr. ETPC z dnia 4 października 2005 r. (skarga nr 9190/03). LEX nr 157757.

Wyr. ETPC z dnia 7 października 2008 r. (skarga nr 6767/03). LEX nr 456955.

Wyr. ETPC z dnia 13 września 2011 r. w sprawie Bystrowski p. Polsce (skarga nr 15476/06). LEX nr 898138.

Wyr. ETPC z dnia 10 marca 2015 r. (skarga nr 29345/09). LEX nr 1652023.

\section{Źródła internetowe}

Wyr. ETPC z dnia 23 lutego 2016 r. w sprawie Matczak p. Polsce (skarga nr 26649/12). Źródło: https://etpcz.ms.gov.pl/etpccontent/\$N/990000000 000001_I_ETPC_026649_2012_Wy_2016-02-23_001 [dostęp: 14 czerwca 2020]. 